\title{
Vitamin C ikan sidat (anguilla marmorata) asal sungai palu dan danau poso
}

Vitamin $C$ of eel fish (anguilla marmorata) from palu river and poso lake

\author{
Jamaluddin $^{1}$, Agustinus Widodo ${ }^{1}$, Anita Tri Damayanti ${ }^{1 *}$ \\ ${ }^{1}$ Jurusan Farmasi, Fakultas Matematika dan Ilmu Pengetahuan Alam, Universitas Tadulako, Palu \\ E-mail: trideanita@gmail.com
}

Naskah diterima : 23-05-2018

Naskah diterbitkan:18-06-2018

\begin{abstract}
Background \& Objective: Sidat Fish (Anguilla marmorata (Q.) Gaimard) has high nutrition or nutritional advantages such as vitamin $\mathrm{A}$, vitamin $\mathrm{B}$, vitamin $\mathrm{C}$, vitamin $\mathrm{D}$, vitamin $\mathrm{E}$, protein, minerals, and fatty acids that are good for health. This research was purposed decide the difference of the vitamin c level of Sidat Fish (Anguilla marmorata (Q.) Gaimard), Glass eel fase, Yellow eel and Silver eel from poso lake and estuary of Palu River. Materials and Methods: The testing of vitamin c using substance the meet of Sidat Fish (Anguilla marmorata (Q.) Gaimard) Glass eel fase, Yellow eel and Silver eel, vitamin C, metaphospat acid and aquadest with the HPLC method (High Perfomance Liquid Chromatography) with Purposive Sampling technique seen based on the size, place, and fish fase as the requirement for the sample taking. Results: The result showed that Sidat Fish (Angilla marmorata (Q.) Gaimard) with Glass eel fase, Yellow eel and Silver eel from Poso lake and estuary of Palu river was not detected there was the content of vitamin C. Conclusion: Sidat fish (Anguilla marmorata (Q.) Gaimard) does not contain vitamin C.
\end{abstract}

Keywords: Vitamin C, Anguilla marmorata, Poso Lake and Palu, Glass eel, Yellow eel and Silver eel

\section{ABSTRAK}

Pendahuluan \& Tujuan: Ikan sidat (Anguilla marmorata (Q.) Gaimard) memiliki keunggulan gizi atau nutrisi yang tinggi seperti vitamin $\mathrm{A}$, vitamin $\mathrm{B}$, vitamin $\mathrm{C}$, vitamin $\mathrm{D}$, vitamin $\mathrm{E}$, protein, mineral, dan asam lemak yang baik bagi kesehatan. Penelitian ini bertujuan untuk menentukan perbedaan kadar vitamin C ikan sidat (Anguilla marmorata (Q.) Gaimard) fase Glass eel, Yellow eel, dan Silver eel asal danau Poso dan muara sungai Palu. Bahan dan Metode: Pengujian kadar vitamin $\mathrm{C}$ menggunakan bahan berupa daging ikan sidat (Anguilla marmorata (Q.) Gaimard) fase Glass eel, Yellow eel, dan Silver eel dengan metode HPLC (High Performance Liquid Chromatography) dengan teknik Purposive Sampling yang berdasarkan ukuran, tempat dan fase ikan sebagai syarat untuk pengambilan sampel. Hasil: Ikan sidat (Anguilla marmorata (Q.) Gaimard) pada fase Glass eel, Yellow eel, dan Silver eel asal danau Poso dan muara sungai Palu tidak terdeteksi adanya kandungan vitamin C. Kesimpulan: Ikan sidat (Anguilla marmorata (Q.) Gaimard) tidak mengandung vitamin $\mathrm{C}$.

Kata Kunci: Vitamin C, Anguilla marmorata, danau Poso dan Palu, Glass eel, Yellow eel, Silver 


\section{A. Pendahuluan}

Ikan air tawar di Sulawesi tercatat sebanyak 62 jenis dan 52 di antaranya merupakan jenis ikan endemik. Beberapa diantaranya adalah Ikan gabus (Channa striata), betok (Anabas testudineus), nilem (Osteochilus hasselti), sidat/sogili (Anguilla marmorata), nila (Oreochromis niloticus), anasa (Nomorhampus celebensis), tempel batu (Tamanka sarasinorum) dan rono (Oryzias nigricans) (Mamangkey 2010). Di Sulawesi populasi ikan sidat ditemukan di beberapa sungai dan danau. Potensi perkembangbiakan ikan sidat di Sulawesi sangat besar. Penyabaran ikan sidat di Sulawesi yang terbanyak di danau Poso dan sungai Palu (Fadly Y.Tantu, 2014).

Ikan sidat (Anguilla sp.) merupakan jenis ikan yang laku di pasar internasional (Jepang, Hongkong, Jerman, Italia, dan beberapa negara lainnya). Dengan demikian ikan ini memiliki potensi sebagai komoditas ekspor (Affandi, 2005). Kurangnya pemahaman dan perhatian masyarakat setempat akan nilai ekonomis sidat menyebabkan potensi ikan sidat yang cukup melimpah di sungai dan danau kurang mendapat perhatian. Ikan sidat merupakan komoditas yang berharga dan dapat diandalkan bagi masyarakat setempat. Semakin tingginya permintaan ikan sidat maka akan semakin meningkat pula usaha penangkapan ikan sidat. Hal ini dapat meningkatkan usaha penangkapan para nelayan dan dapat dijadikan sebagai mata pencaharian bagi masyarakat.

Ikan sidat (Anguilla sp.) merupakan ikan dari ordo Anguilliformes yang tergolong dalam ikan katadromus. Ikan katadromus yaitu ikan yang bermigrasi diantara perairan tawar dan perairan laut. Ikan sidat memiliki siklus dengan beberapa tahapan, yaitu larva Leptochepalus (umur SF (Short finned) 3,5-6 bulan dengan panjang $55-60 \mathrm{~mm}$, LF (Long finned) 4 bulan dengan panjang 50-55 mm), glass eel (umur SF 4,5-7 bulan dengan panjang 55-60 mm, LF 5,56,5 bulan dengan panjang $50-55 \mathrm{~mm}$ ), Elver (umum $<1-5$ tahun dengan panjang $\leq 30 \mathrm{~cm}$ ), Yellow eel (umur 5 tahun lebih dengan panjang panjang $>30 \mathrm{~cm}$ ) dan Silver eel umur 10-20 tahun lebih ( jantan $\mathrm{SF} \leq$ dengan $500 \mathrm{~mm}$ dengan berat 250 $\mathrm{g}$, betina $\mathrm{SF} \leq 1,3 \mathrm{~m}$ dengan berat $6 \mathrm{~kg}$ sedangkan jantan $\mathrm{LF} \leq 650 \mathrm{~mm}$ dengan berat $600 \mathrm{~kg}$, betina $\mathrm{LF} \leq 1,6 \mathrm{~mm}$ dengan berat $22 \mathrm{~kg}$ ) (McKinnon, LJ, 2006 ).

Ikan sidat memiliki keunggulan gizi atau nutrisi yang tinggi seperti karbohidrat, protein, lemak, fosfor, zat besi, vitamin $\mathrm{A}$, vitamin $\mathrm{B}$, vitamin $\mathrm{C}$ dan kadar air (Affandi R, 2001). Fungsi Vitamin $\mathrm{C}$ untuk tubuh manusia adalah untuk kesehatan gigi dan gusi, pembentuk sel darah merah, menjaga sistem imun tubuh, dan antioksidan. Salah satu sumber vitamin C adalah Ikan karena sangat baik dan prospektif bagi tubuh manusia (Panangan dkk, 2012).

Beberapa penelitian terkait analisis kandungan vitamin $\mathrm{C}$ ikan air tawar telah dilakukan diantaranya oleh Hengky S (2010), menyatakan bahwa ikan lele mengandung vitamin $\mathrm{C}$ pada bagian ovarium sebesar $155,98 \mu \mathrm{g} / \mathrm{g}$. Rita J (2010) juga telah meneliti kandungan vitamin $\mathrm{C}$ pada ikan belut sebesar 2.00 $\mathrm{mg} / 100 \mathrm{~g}$ vitamin C. Pada tahun 2009, Ozyyurt et al. melakukan penelitian dan dia menyatakan bahwa ikan pike tengger (sander lucioperca) dengan bobot $135.67 \pm$ $35.8 \mathrm{~g}$ mengandung vitamin C 1.91 $\mathrm{mg} / 100 \mathrm{~g}$, ikan mas (Cyprinus carpio) dengan bobot $780.52 \pm 50.3 \mathrm{~g}$ mengandung $1.14 \mathrm{mg} / 100 \mathrm{~g}$, dan ikan lele Eropa (Silurus glanis) dengan bobot $690.78 \pm 40.84 \mathrm{~g}$ mengandung vitamin $\mathrm{C}$ $2.15 \mathrm{mg} / 100 \mathrm{~g}$. Penelitian di atas menunjukkan bahwa jenis ikan yang berbeda memiliki kadar vitamin $\mathrm{C}$ yang berbeda pula.

Selama ini penelitian ikan sidat cenderung terfokus pada sungai dan danau Poso, sehingga ketersediaan data di sungai atau danau lainnya, termasuk sungai Palu masih sangat kurang. Oleh karena itu pengujian vitamin $\mathrm{C}$ dalam ikan sidat (Anguilla marmorata (Q.) Gaimard) fase Glass eel, Yellow eel, dan Silver eel asal danau Poso dan muara sungai Palu penting dilakukan untuk melengkapi data kandungan vitamin $\mathrm{C}$ ikan sidat yang ada di Sulawesi 


\section{B. BAHAN DAN METODE}

Alat

High

Performance

Liquid

Chromatography (HPLC)18-52/MU/SMM-

SIG, Neracan analitik, beaker glass, labu ukur, gelas ukur, Pipet tetes, labu erlenmeyer, vial dan blender

Bahan

Ikan sidat (Anguilla marmorata (Q.) Gaimard) yang berukuran glass eel, yellow eel, dan silver eel dari danau Poso dan Muara Sungai Palu, Larutan standar vitamin C, asam metaphospat, aquadest.

\section{Preparasi Sampel}

Tahap preparasi sampel dimulai dengan pencucian sampel menggunakan air mengalir untuk membersihkan lendirnya, kemudian organ dalamnya (isi perut dan insang) dan dilakukan pencucian kembali. Setelah sampel bersih, dilanjutkan ke tahap pemfiletan menggunakan pisau stainles steel. Tujuannya untuk memisahkan tulang dari dagingnya. Proses selanjutnya yakni penyiangan yang dilakukan dengan mencabut tulang-tulang yang masih menempel pada daging, dan tahapan yang terakhir dilakukan pemotongan sampel menjadi ukuran kecil, lalu dihaluskan daging ikan tersebut dengan menggunakan blender hingga daging sampel ikan sidat homogen

\section{Penyiapan Larutan Standar}

Ditimbang dengan teliti $25 \mathrm{mg}$ standar vitamin $\mathrm{C}$ ke dalam labu ukur $25 \mathrm{~mL}$, dilarutkan dengan asam metaphospat $4 \%$ dicukupkan dengan asam metaphospat sampai tanda batas, kocok hingga homogen (Larutan Standar Induk Vitamin C $1000 \mathrm{mg} / \mathrm{L}$ ).

\section{Penyiapan Larutan Sampel}

Dipipet $0.50,1 \mathrm{~mL}$ larutan standar antara vitamin C $10 \mathrm{mg} / \mathrm{L}, 0.25,0.50,1$ $\mathrm{mL}$ larutan standar antara vitamin C 100 $\mathrm{mg} / \mathrm{L}, \quad 0.25, \quad 0.5, \quad 0.75,1 \mathrm{~mL}$ larutan standar induk vitamin C $1000 \mathrm{mg} / \mathrm{L} \mathrm{ke}$ dalam masing-masing labu ukur $10 \mathrm{~mL}$. Diencerkan dengan asam metaphospat 2 $\%$ hingga tanda tera dan dihomogenkan. Konsentrasi Deret Standar Vit C Kurva I : $0.5,1,2.5,5,10 \mathrm{mg} / \mathrm{L}$ Konsentrasi Deret Standar Vit C Kurva II : 10, 25, 50, 75, $100 \mathrm{mg} / \mathrm{L} \mathrm{mg} / \mathrm{L}$. Saring larutan dengan penyaring $0,45 \mu \mathrm{m}$ ke dalam vial.
Suntikkan larutan ke sistem HPLC.

\section{Pengujian Sampel}

Sampel yang telah ditimbang dihomogenkan dengan asam metaphospat $2 \%$ didalam labu 10 mL.Diultrasonik selama 15 menit. Ditambahkan asam metaphospat $2 \%$ hingga tanda tera, dihomogenkan. Larutan contoh disentrifuge $14000 \mathrm{rpm}$ selama 3 menit. Saring supernatan dengan membrane filter $0.45 \mu \mathrm{m}$ ke dalam vial. Injeksikan ke sistem HPLC.

\section{Analisis Data}

Perhitungan kadar vitamin dalam sampel dengan menggunakan kurva kalibrasi yang sesuai dengan luas area yang masuk ke dalam kurva standar, dengan persamaan garis: $\mathrm{Y}=\mathrm{bx}+\mathrm{a}$, dengan rumus sebagai berikut :

kadar vitamin C (ppm)

$$
=\frac{(A . s p l-a) \times V(m L) \times f p}{b \times W s p l \text { atau } V \text { spl }}
$$

Keterangan :

A.spl = Luas area sampel

a $\quad=$ Intercept dari kurva kalibrasi standar

b = Slope dari kurva kalibrasi standar

Fp $\quad=$ Faktor pengenceran sampel

$\mathrm{V} \quad=$ Volume labu akhir sampel $(\mathrm{ml})$

$\mathrm{W} \mathrm{spl}=$ Bobot penimbangan sampel (gram)

Vspl = Volume pemipetan sampel (ml)

\section{HASIL}

Tabel 1 dan 2 menunjukkan bahwa ikan sidat (Anguilla marmorata (Q.) Gaimard) asal danau Poso dan muara air sungai Palu tidak terdeteksi vitamin C.

Tabel 1. Kadar vitamin $\mathrm{C}$ ikan sidat (Anguilla marmorata (Q.) Gaimard) asal danau Poso

\begin{tabular}{lcr}
\hline \multicolumn{1}{c}{ Fase } & Bobot $(\mathbf{g})$ & Kadar \\
\hline Glass eel & 1.1249 & nd \\
Yellow eel & 1.0733 & nd \\
Silver eel & 1.1014 & nd \\
\hline
\end{tabular}

Keterangan : nd : not detected

Tabel 2. Kadar vitamin C ikan sidat (Anguilla marmorata (Q.) Gaimard) asal muara sungai Palu

\begin{tabular}{lcc}
\hline Fase & Bobot (g) & Kadar \\
\hline Glass eel & 1.0396 & nd \\
Yellow eel & 1.0427 & nd \\
Silver eel & 1.1919 & nd
\end{tabular}

Keterangan : nd : not detected 


\section{PEMBAHASAN}

Berdasarkan hasil penelitian, Hasil analisis Vitamin $\mathrm{C}$ pada ikan sidat (Anguilla marmorata (Q.) Gaimard) fase Glass eel, Yellow eel, dan Silver eel yaitu Not detected. Beberapa Faktor yang mempengaruhi tidak terdeteksi adanya vitamin $\mathrm{C}$ yaitu karena kadar vitamin $\mathrm{C}$ yang ada dalam ikan sidat (Anguilla marmorata (Q.) Gaimard) sangat kecil dan vitamin $\mathrm{C}$ tersebut juga bercampur dengan senyawa lain sehigga tidak terdeteksi oleh HPLC (High Performance Liquid Chromatography) (SIG, 2018).

Vitamin $\mathrm{C}$ merupakan nutrien yang dibutuhkan untuk proses fisiologi hewan, termasuk ikan. Vitamin ini banyak disintesis secara alami baik dari tanaman maupun hewan. Di dalam tubuh manusia vitamin ini adalah senyawa organik yang harus ada pada diet dalam jumlah tertentu untuk mempertahankan integritas dan metabolisme tubuh yang normal (Slominski, 2010). Vitamin ini dapat terserap sangat cepat didalam alat pencernaan, masuk kedalam darah dan dibagikan ke seluruh jaringan tubuh. Pada umumnya tubuh menahan vitamin $\mathrm{C}$ sangat sedikit dan yang tidak diserap dikeluarkan melalui urin. Vitamin C (Asam askorbat) mudah larut dalam air dan tidak larut dalam pelarut organik non polar yaitu eter, kloroform dan benzen (Depkes RI, 1979).

Penelitian ini dilakukan untuk mendapatkan perbandingan vitamin $\mathrm{C}$ dari ikan sidat spesies (Anguilla marmorata (Q.) Gaimard) fase Glass eel, Yellow eel, dan Silver eel dari Danau Poso dan Muara Sungai Palu. Ikan sidat spesies (Anguilla marmorata (Q.) Gaimard) yang merupakan ikan yang hidup di Sulawesi Tengah. Ikan spesies ini memiliki ciri warna kulit kekuningan dengan bintik bewarna hitam. Ikan sidat spesies (Anguilla marmorata (Q.) Gaimard) merupakan satu spesies yang memiliki nilai ekonomis tinggi dan permintaan global yang meningkat (CITES, 2007 ; Sidatmoa, 2009). Keunggulan dari ikan sidat selain dari segi ekonomi adalah dilihat dari kualitas ikan sidat itu sendiri yaitu kandungan gizinya. Pada penelitian ini dilakukan analisis kandungan vitamin
C.

Sampel yang diteliti ikan sidat (Anguilla marmorata (Q.) Gaimard) fase glass eel (5 bulan dengan panjang 5,5-6 $\mathrm{cm}$ ) yellow eel (umur 5 tahun lebih dengan panjang $45-50 \mathrm{~cm}$ ) dan silver eel (umur 10 tahun lebih Ukuran 54-60 cm). Pada Fase glass eel ikan sidat sudah menyerupai sidat secara utuh namun masih belum ada pigmentasi pada tubuhnya sehingga bening seperti kaca. Pada fase Yellow eel atau sering disebut Stadia fingerling bentuknya seperti sidat dewasa lainnya namun organ kelamin belum berkembang secara sempurna. Selanjutnya sidat tumbuh dan warnanya akan berubah menjadi perak (Xanthocrhomatism) yang terlihat pada dasar perutnya. Perkembangan sidat menjadi silver eel terjadi di air tawar ( Sasono, 2001). Kandungan gizi setiap ikan berbeda-beda tergantung pada jenis ikan antar individu dalam spesies, dan antar bagian tubuh dari satu individu ikan. Perbedaan ini dapat disebabkan oleh beberapa faktor yaitu umur, laju metabolisme, pergerakan ikan, makanan, serta masa reproduksi. Selain itu perbedaan kandungan gizi daging ikan juga tergantung dari umur, habitat dan kebiasaan makan (Okada, 1990).

Perbedaan kadar vitamin $\mathrm{C}$ pada suatu organisme dapat disebabkan oleh perbedaan dari jenis makanan yang dikonsumsi ikan tersebut dan kondisi lingkungan hidup (Santoso, 2008). Kandungan vitamin $\mathrm{C}$ yang terdapat pada suatu biota perairan dipengaruhi oleh makanan yang dimakannya serta kemampuan untuk menyerap kandungan vitamin $\mathrm{C}$ yang terdapat pada lingkungan perairan tempat makhluk hidup tersebut tinggal. Selain itu, perbedaan ini juga disebabkan jenis spesies, konsentrasi vitamin $\mathrm{C}$ dalam habitatnya dan fase pertumbuhan serta perkembangan betuk fisik dari suatu biota.

Pada tahap analisis Vitamin C ikan sidat dilakukan menggunakan metode HPLC (High Performance Liquid Chromatography). Penggunaan kolom pada alat HPLC kali ini yang digunakan adalah $\mathrm{C} 18$ (4.6 x $250 \mathrm{~mm})$ dengan fase gerak Tri Fluoro Asetat 0,1\%. Detektor 
yang digunakan adalah PDA (Phaotodiode Array) dengan panjang gelombang $245 \mathrm{~nm}$, hal ini dapat diartikan bahwa detektor memancarkan gelombang pada panjang gelombang 245 $\mathrm{nm}$ dan menangkap emisi fluoresensi yang dipancarkan oleh sampel, sehingga metode HPLC sangat tepat digunakan untuk senyawa-senyawa yang tidak mudah menguap atau non-volatil, dan stabil.

HPLC (High Performance Liquid Chromatography) merupakan suatu teknis analisis yang paling cepat berkembang. Cara ini ideal untuk analisis penetapkan kadar senyawa-senyawa tertentu seperti asam amino, asam nukleat, protein dalam cairan fisiologis, menentukan kadar senyawa-senyawa aktif obat, sampel yang berasal dari lingkungan, karena sederhana dan kepekaannya tinggi (Gandjar \& Rohman, 2007). Vitamin C adalah senyawa yang memiliki sifat polar dan gugus kromofor yang dimilikinya menyebabkan senyawa ini dapat menyerap sinar UV. Karakteristik senyawa ini memungkinkan analisis dengan teknik HPLC menggunakan kolom nonpolar seperti C18 dan fase gerak polar seperti metanol atau air.

Kolom pada alat HPLC kali ini yang digunakan adalah C18. Kolom C18 merupakan fase diam yang paling banyak digunakan karena mampu memisahkan senyawa-senyawa dengan kepolaran yang rendah, sedang, maupun tinggi. Oktil atau rantai alkil yang lebih pendek lagi lebih sesuai untuk solut yang polar (Abdul R, 2009).

Penggunaan detektor PDA (Phaotodiode Array) memberikan beberapa kemudahan. Pengukuran dapat dilakukan pada banyak panjang gelombang secara simultan, sehingga dapat diperoleh komposisi suatu sampel pada rentang panjang gelombang yang diinginkan. Keunggulan lain, rentang panjang gelombang dapat menghasilkan pola spektra dari puncak-puncak yang diperoleh sehingga secara kualitatif dapat ditentukan tanpa harus menganalisis marker (Briton 1995; Choo 1994).

Larutan standar yang digunakan adalah asam askorbat dengan tujuan sebagai faktor koreksi kesalahan volumetrik selama persiapan sampel dan pengoreksi hilangnya residu vitamin $\mathrm{C}$ selama proses hidrolisis yang akan dideteksi dengan berkurangnya standar internal, sehingga penggunaan larutan standar internal dapat meningkatkan presisi.

\section{E. KESIMPULAN}

Ikan sidat (Anguilla marmorata (Q.) Gaimard) fase Glass eel, Yellow eel, Silver eel asal Danau Poso dan Muara Sungai Palu tidak memiliki kadar kandungan vitamin $\mathrm{C}$

\section{F. DAFTAR PUSTAKA}

Abdul Rohman, (2009) Kromatografi Untuk Analisis Obat Edisi I Yogyakarta : Graha Ilmu

Affandi, R.,(2001). Budidaya Ikan Sidat. Bogor: Fakultas Perikanan dan Ilmu Kelautan IPB.

Affandi, R.,(2005). Strategi pemanfaatan sumber daya ikan sidat. J. Iktiologi Indonesia. 5(2):77-81.

Britton, G., Liaaen-Jensen, S. \& Pfander, H. (1995). Carotenoids Volume 1A: Isolation and Analysis. Berlin: Birkhauser Verlag.

CITES, (2007). CoP14 Prop. 18. Consideration of Proposals for Amendment of Appendices I and II Inclusion of Anguilla anguilla (L.) in Appendix II in accordance with Article II §2(a). 37 hal.

Depkes RI., (1995). Materia Medika Indonesia. Jilid VI. Jakarta: Departemen Kesehatan

Fadly Y.Tantu, (2014). Budidaya Belut dan Sidat. Edisi Revisi. Penerbit Penebar Swadaya. Jakarta. 87 hal.

Gandjar, I.G., dan Rohman, A., (2007). Kimia Farmasi Analisis.Yogyak arta:Penerbit Pustaka Pelajar. Hal. 378-394

Mamangke, J. J., (2010). Biopopulasi Ikan Endemik Butini ( Glossogobius matanensis ) Di Danau Towuti, Sulawesi Selatan. Disertai ( S3) sekolah pascasarjana Institut Pertanian Bogor.

McKinnon, L.J., (2006). A review of eel 
biology : Knowledge and Gaps, EPA Victoria and Audents Investments Pty, Ltd

Okada, M. (1990) Fish and Raw Material. In Science of Processing Marine Food Product. Vol. 1. Japan Internasional Coorporation Agency. Hyoga Internasional Cente Japan.

Panangan A. T., dkk., (2012). Analisis Kualitatif dan Kuantitatif Asam Lemak Tak Jenuh Omega-3, Omega-6, Omega6 dan Karakterisasi Minyak Ikan Patin (Pangasius pangasius). Jurnal Penelitian Sains Volume 15 Nomor 3

Saraswanti Indo Genetech (SIG). (2018). Pengujian vitamin c Metode HPLC. PT Saraswanti Indo Genetech.
Santoso (2008). Budidaya Belut dan Sidat Edisi Revisi. Jakarta : Penebar Swadaya

Sasono AD. (2001) Kebiasaan Makan Ikan Sidat (Anguilla bicolor) di Desa Citepus, Kecamatan pelabuhan Ratu dan Desa Cimaj, Kecamatan Cisolok. Skripsi. Institut pertanian Bogor.

Slominski et al., (2010). Melanin Pigmentation in Mammalian Skin and Its HormonalRegulation. 